\title{
The Misguided Assault on the Consumer Welfare Standard in the Age of Platform Markets
}

\section{A. Douglas Melamed ${ }^{1} \cdot$ Nicolas Petit $^{2,3,4}$}

Published online: 11 February 2019

(c) The Author(s) 2019

\begin{abstract}
In this paper, we discuss whether the consumer welfare (CW) standard needs to be replaced or revised in order for antitrust law to deal effectively with the economic challenges of the platform economy. We argue that both the general and platformspecific assaults on the $\mathrm{CW}$ standard are misguided, that the $\mathrm{CW}$ standard is capable of addressing the economic concerns that critics have raised, and that the proposed alternatives would make things worse - not better.
\end{abstract}

Keywords Consumer welfare $\cdot$ Antitrust · Competition · Platforms · Monopoly · Market power

\section{Introduction}

We live an age of populism (Goldberg 2018). Though public opinion polls suggest moderate concern about corporate power and big business (Gallup 2018), ${ }^{1}$ established political figures from the left and right are trying to revive an anti-monopoly agenda. They often appeal to the "romantic" tradition of the US antimonopoly movement in the gilded age (Langlois 2018).

In this new conversation, "big is bad" rhetoric is no longer used to implicate big oil, big steel, or big finance. Oligopoly firms from all sectors are criticized for their contribution to high prices, low wages, income inequality, and slow productivity growth. And in information industries, consumer-facing platform-based firms-such as Facebook, Amazon, Netflix, and Google-are attacked for the additional reason

\footnotetext{
A. Douglas Melamed

dmelamed@law.stanford.edu

1 Stanford Law School, Stanford, USA

2 University of Liege, Liège, Belgium

3 University of South Australia, Adelaide, Australia

4 Hoover Institution, Stanford University, Stanford, USA
}

1 See https://news.gallup.com/poll/5248/big-business.aspx (accessed 22 January 2019). 
that they are said to undermine the political process. Recently, respected news outlets-such as The Economist and the Financial Times-have called for government action to disperse platform-based firms' economic and political power.

The concern about corporate concentration is not just a byproduct of political alienation or scapegoating in a context of technological change. Studies by economists report a secular and broad-based increase in industry concentration and wealth inequality, though their magnitudes and interpretation are disputed (Shapiro 2017; White and Yang 2017). ${ }^{2}$ Recent empirical works attribute observed increases in firms' markups to a rise in market power and a decline in competition (Barkai 2016; De Loecker and Eeckhout 2017; Diez et al. 2018). Though the causes of alleged market power growth are diverse, rapid technological change is said to be a common factor that enables firms to create and preserve market power (De Loecker and Eeckhout 2017).

In the political economy literature, some warn that the interaction of increased industry concentration and corporate power with politics is both a threat "to the functioning of the free market economy and to the economic prosperity it can generate, and a threat to democracy as well" (Zingales 2017). In information industries, a common perception is that "new business models developed by corporate social media redefine power relations", including in labor markets or in the political system (Langlois and Elmer 2013).

Concerns about industry concentration and corporate power in the twenty-first century naturally lead to discussions of antitrust policy. A recent study suggests that weak antitrust institutions and lax product market regulation explain the relatively higher degree of industry concentration and profits observed in the US compared to the EU (Guttiérez and Philippon 2018). Many scholars have been discussing ideas to make antitrust enforcement more aggressive (Baker et al. 2018).

Some critics go further and argue that antitrust law is fundamentally flawed and that the "consumer welfare" ("CW") standard on which contemporary antitrust is based prevents antitrust law from effectively addressing the new problems of industry concentration and corporate power (Steinbaum and Stucke 2018). Broadly speaking, the CW standard embodies the idea that antitrust laws promote economic welfare and are intended to protect economic agents from the predictable harms that are caused by improperly obtained market power. ${ }^{3}$ But according to some critics, under $\mathrm{CW}$-driven antitrust, the courts "rewrite doctrine not to protect consumers, but to preserve the freedom of dominant and other powerful corporations" (Vaheesan 2018). Antitrust law thus needs to be fundamentally reformed, these critics argue, perhaps by legislation, to replace the crabbed CW paradigm. Wu (2018) offers an

\footnotetext{
${ }^{2}$ Shapiro suggests that census data show only a modest increase in average concentration in four-digit NAICS industries.

3 A similar definition is given by Posner in relation to economic welfare (Posner 2001): noting that everyone today agrees that "the only goal of the antitrust laws should be to promote economic welfare, but also agrees on the essential tenets of economic theory that should be used to determine the consistency of specific business practices with that goal". Posner (2001). Additional debates exist today on the distinction between consumer welfare and total welfare (Blair and Sokol 2013), or between consumer welfare and consumer surplus (Orbach 2011), but these debates are immaterial to the analysis and argument in this paper.
} 
alternative test: antitrust laws should ask whether conduct is "competition on the merits" or "rather, an effort to disable or subvert the competitive process".

According to the critics, the flaws of the $\mathrm{CW}$ standard are nowhere better seen than in digital markets in which matchmakers-such as Google, Amazon, Facebook, Uber, or Netflix - exploit large troves of personal data and gigantic computing power to convince distinct groups of users to interact through their platform by reducing friction (Evans and Schmalensee 2017) and improving convenience (Wu 2018). The economics of multi-sided platform markets in general-and of "cross-platform network externalities", "winner takes all" effects, and "information goods" in particular-increase the returns to long-term growth and scale strategies, rather than short term revenue and profit maximization. Firms that operate in platform markets have incentives to support aggressive low-price strategies, leveraging across multiple lines of businesses, discrimination against digital complements, and defensive growth through predatory startup acquisitions and M\&A (Khan 2017). In addition, as platform-based firms grow and tip towards monopoly, they become "massive employers" (Naidu et al. 2018) that obtain the ability and incentive to act as monopsonists in labor markets: reducing wages, increasing automation, and eventually hurting employees (Sunstein 2018).

Nothing of this, it is said by some, can be remedied in a CW-driven antitrust system in which the liability standard prohibits only conduct that leads to output reduction and price increases. Moreover, the economic language of $\mathrm{CW}$ is blind to the political harms that are created by the accumulation of personal data by digital platforms, including its adverse effects on free speech and privacy, opportunistic data grabs by non-State actors, and distortions of the democratic process (Pasquale 2013).

In this paper, we discuss whether the $\mathrm{CW}$ standard needs to be replaced or revised in order for antitrust law to deal effectively with the economic challenges of the platform economy. By platforms, we mean firms "whose core mission is to enable and to generate value from interactions between users" (Belleflamme and Peitz 2018). We argue that both the general and platform-specific assaults on the CW standard are misguided, that the CW standard is capable of addressing the economic concerns critics have raised, and that the proposed alternatives would make things worse-not better. Populist criticisms of antitrust policy are as wrong in today's digital economy as they were in the past, when scholars criticized the dominant "efficiency" paradigm and contrasted it with the "competitive process", "market access", or "consumer choice" (Fox 2007).

We do not discuss here calls for a broadened antitrust law to address current political and other non-economic problems because we believe non-economic problems should be dealt with by other laws that are designed for those specific purposes. As Turner (1987) explained 30 years ago, incorporating non-economic goals into antitrust law "would broaden antitrust's proscriptions to cover business conduct that has no significant anticompetitive effects, would increase vagueness in the law, and would discourage conduct that promotes efficiencies not easily recognized or proved". Nor do we address calls for multifaceted regulatory intervention beyond antitrust law to address perceived problems of concentrations of 
wealth or economic capture that are not manifest in market power: the ability to extract supra-competitive terms of trade from trading partners (Khan 2018a, b, c).

We also leave aside the purely legal, and originalist, argument that $\mathrm{CW}$ takes antitrust away from Congress' intent in 1890. Antitrust has long been understood to evolve over time through a common law-like process, enriched by the jurisprudence of courts under the impetus of private plaintiffs and the Federal Trade Commission (FTC) and Justice Department. As the Supreme Court explained in State Oil v Khan, "the general presumption that legislative changes should be left to Congress has less force with respect to the Sherman Act". 4

This article is organized as follows: In part 2, we identify and describe the scholarly discussion on the $\mathrm{CW}$ standard in the age of platform markets. In part 3, we explain what we believe to be the fundamental flaw in the assault on CW: It is based on a misunderstanding of the $\mathrm{CW}$ standard. In part 4, we assess the main operational criticisms that are levelled at $\mathrm{CW}$ and explain why we think they are misplaced in general and with respect to modern platform businesses in the digital economy. In part 5 , we explain why the alternatives to $\mathrm{CW}$ that have been suggested by its critics would not be an improvement.

\section{CW's Various Critics}

Two groups of critics can be distinguished: A first group-which we call "progressive"-focuses on the need to adapt antitrust doctrine and policy to the digital economy and more generally to new forms of competition. ${ }^{5}$ Platform-based firms hold forms of market power that create idiosyncratic harms, and some adjustments are needed to avoid type-II errors. This group is not as much concerned about CW in economic theory as it is critical of the mainstream doctrinal and policy implementation of CW (Patterson 2017; Caves and Singer 2018; Candeub 2014). In particular, it tends to believe that so-called Chicago School economics continues to have too much influence in the application and formulation of contemporary antitrust policy and doctrine. This group also often advocates consideration of additional goals in antitrust, such as consumer choice, market access, fairness, or trust. ${ }^{6}$

A second group—which are sometimes called "New Brandeis"—advocates more radical antitrust reform. ${ }^{7}$ Their fundamental thesis is that modern antitrust doctrine has abandoned much of the broader normative objectives of Congress-including the preservation of small firms and dispersion of economic power-when it enacted the antitrust laws. Some in this group favor: new legislation that would enact

\footnotetext{
4 State Oil Co. v. Khan, 522 U.S. 3, 20 (1997).

5 See Alexis (2017). For prior use of the term "progressive antitrust", See Balto (2008) from http://www. dcantitrustlaw.com/assets/content/documents/CAP/A\%20Progressive\%20Vision.pdf.

${ }^{6}$ In the past, antitrust scholars have made similar argument though not specifically in relation to platforms (Fox 1986; Lande 2001).

7 This group includes Adam Candeub, Sally Hubbard, Lina Khan, Barry Lynn, Nathan S. Newman, John M. Newman, Matthew Stoller, Zephyr Teachout, Sandeep Vaheesan, and Ramsi Woodcock. A list of representative work is provided in the bibliography.
} 
standards for "no fault" deconcentration; regulation of platform-based firms including non-discrimination duties and must-carry obligations; restrictions on M\&A; and the creation of new institutions, such as a Federal Search Commission (Bracha and Pasquale 2008).

The progressive and "New-Brandeis" antitrust groups share two features: First, both build the case for change by pointing to what they regard as shortcomings in existing CW-driven antitrust. Second, both insist on quick changes in enforcement practice, in the hope that this will incrementally usher in doctrinal reform. The New Brandeis view seems to support evolution of antitrust doctrine only as second-best alternative to legislative change (Khan and Vaheesan 2017).

\section{Consumer Welfare, Value Maximization, and Economic Outcomes}

The critics of the CW standard are motivated by: concerns about increasing concentration and market power in the economy, especially in digital platforms; a belief that antitrust law has not adequately guarded against such increases; and a diagnosis that puts the blame on the $\mathrm{CW}$ standard. Even if the first two concerns are correctand that remains an open question - the diagnosis reflects a misunderstanding of the CW standard.

\subsection{Antitrust Law is Proscriptive, Not Prescriptive}

Some critics describe CW-driven antitrust as an "exercise in social planning" in which antitrust agencies and courts "test" the lawfulness of firm conduct by "exclusive" scrutiny of its ability to deliver a "welfare" maximizing "outcome" (Wu 2018). They complain that the unit of analysis of $\mathrm{CW}$ is "measurable" short-term consumer prices (Vaheesan 2018) and take literally the Supreme Court's statement in Reiter $v$ Sonotone that the Sherman Act is a "consumer welfare prescription". 8

As these critics see it, antitrust laws instruct agencies and courts to maximize CW. That view, however, reflects a fundamental misunderstanding of antitrust law. US antitrust law is concerned with private conduct that restrains trade. This is readily apparent in the text of the Sherman Act. The statute is proscriptive, not prescriptive (Areeda 1972; Fox 2008a, b). It bans specific kinds of agreements (Section 1) and specific kinds of conduct (Section 2). As construed by the courts in hundreds of cases, the antitrust laws thus prohibit under some circumstances: (1) collaboration among firms that would otherwise be rivals; and (2) exclusion or weakening of rivals or potential rivals.

Similarly, Section 7 of the Clayton Act prohibits mergers and acquisitions where the effect "may be substantially to lessen competition". Nothing in the statutory language calls upon courts or agencies to require firms to take affirmative steps to

\footnotetext{
${ }^{8}$ Reiter v. Sonotone Corp., 442 U.S. 330 (1979).
} 
maximize consumer welfare or suggests that the statute is intended to prohibit conduct just because it does not maximize welfare.

The $\mathrm{CW}$ standard in no way departs from this proscriptive frame. The $\mathrm{CW}$ paradigm serves two very different but nonetheless important functions that do not involve requiring anyone to maximize consumer welfare: First, the $\mathrm{CW}$ paradigm makes clear that the antitrust laws are about conduct that reduces or is likely to reduce economic welfare and is not intended to prevent noneconomic harms such as harm to the political process or to serve other social objectives. Second, it provides a criterion to guide the formulation and case-by-case application of the specific rules that are used to identify prohibited, anticompetitive conduct.

$\mathrm{CW}$-driven antitrust has three basic elements: anticompetitive conduct, which is basically conduct that is not efficiency-based competition on the merits; an increase or likely increase in market power; and a causal relation between the two (Melamed 2017). ${ }^{9}$ The law thus prohibits (to oversimplify) conduct that creates or is likely to create market power for reasons that are unrelated to economic efficiency. Conduct is not considered anticompetitive simply because it fails to maximize consumer welfare or because the court or enforcer can imagine an alternative state of affairs that will increase consumer welfare.

Notably, the first two elements are ultimately about protecting the competitive process. The conduct element prohibits only conduct that is not efficiency-based and that can thus create market power only by undermining a healthy competitive process. The market power element means that the anticompetitive conduct reduces or is likely to reduce-compared to the but-for world - the ability and incentives of actual and potential competitors to operate as a competitive constraint in the market.

Business conduct that reduces economic welfare by some means other than creating market power-such as theft, fraud, or pollution-does not violate the antitrust laws. This limitation is not just an inference one might draw from what has not been found to violate the antitrust laws in the past. It is an explicit part of antitrust doctrine. Thus, for example, conduct that enables a firm with market power to avoid non-market pricing constraints does not violate the antitrust laws. ${ }^{10}$ Parallel conduct that does not entail an agreement among competitors is not unlawful even where its effects on consumer welfare are the same as those that would result from a forbidden agreement (Kaplow 2016). And a firm with market power does not violate the antitrust laws by increasing price or otherwise extracting supra competitive rents from trading partners. To the contrary, as the Supreme Court put it in Trinko, "the mere

\footnotetext{
9 The first element plays a lesser role in merger cases because the merger itself is deemed to be anticompetitive conduct if is likely to result in increased market power and cannot be justified by merger-specific efficiencies.

10 See NYNEX Corp. v. Discon, Inc., 525 U.S. 128 (1998) (holding that a scheme to defraud secular regulators in order to charge higher prices did not violate the antitrust laws because it did not affect the defendant's monopoly position and thus the competitive process); Rambus Inc. v. FTC, 522 F.3d 456, 466-67 (D.C. Cir. 2008) (holding conduct that enabled the defendant to avoid a contractual limits on its prices did not violate the antitrust law for the same reason).
} 
possession of monopoly power, and the concomitant charging of monopoly prices, is not only not unlawful; it is an important element of the free-market system". ${ }^{11}$

In this respect, US antitrust law stands in sharp contrast to EU law, which explicitly prohibits setting "unfair purchase or selling prices or other unfair trading conditions" irrespective of whether they distort the competitive process. ${ }^{12}$

\subsection{CW is About Legitimacy and Accountability, Not Disguised Political Choices}

Some critics complain that proponents defend the CW standard on the ground that it purports to be an objective application of economic theory and associated analytical and empirical techniques that renders antitrust "apolitical" (Vaheesan 2018) or "value free" (Fox 1986). But, these critics say, markets and economics are inherently political (Vaheesan 2018); and selecting CW as the single value to maximize is a form of "value-choosing" that is not faithful to the mixed set of socio-political and economic values that were contemplated by Congress in passing the Sherman Act (Wu 2018).

The CW standard does entail value choices: it focuses exclusively on economic welfare and ignores non-economic objectives. As we explain below, however, those choices have little to do with whether antitrust law should be aggressive or passive, conservative or liberal. They are not just an arbitrary selection of outcomes desired by those that shape the law. Instead, they are a means of promoting legitimacy and accountability.

Antitrust law evolves by a common law-like process. The CW standard provides a substantive constraint on discretionary decision-making. If antitrust law were understood to pursue multiple and perhaps conflicting or ill-defined objectives, antitrust decision-makers would be free to make largely unconstrained value choices. The law's embrace of a coherent-even if sometimes difficult to apply—standard thus promotes the legitimacy of antitrust enforcement by reducing the likelihood of arbitrary interventions into market transactions and makes government and judicial decision makers more accountable. By the same token, a limited-purpose antitrust law reduces the scope of private rent-seeking (Dorsey et al. 2018). It also makes the law more predictable and thus facilitates compliance by firms and other economic agents. Thinking of the CW standard as a tool of good governance might explain in part its widespread, multilateral acceptance as the principal standard for assessing competition law throughout the world (ICN 2011).

\footnotetext{
11 Verizon Communications Inc. v. Law Offices of Curtis V. Trinko, LLP, 540 U.S. 398 (2003). Long before Trinko, it was understood that one that gains a monopoly by "skill, foresight and industry" is permitted to reap the fruits of the monopoly. See United States v. Aluminum Co. of America, 148 F.2d 416 (2d Cir. 1945).

12 See Article 102 of the Treaty on the functioning of the EU (and textual references to "limiting production"; "applying dissimilar conditions to equivalent transactions", etc.).
} 


\subsection{Overstating the Chicago School Legacy}

Some critics conflate the $\mathrm{CW}$ standard with the specific views that were expressed by Robert Bork in his influential work in the 1960s and 1970s (Bork 1966, 1967, 1978). According to these critics, Bork intended CW to mean "efficiency" (Khan and Vaheesan 2017) or, to be more precise, "allocative efficiency" (Khan 2017). Allocative efficiency is achieved when output is maximized, and output is "presumptively" not maximized under monopoly where firms have ability and incentive to restrict output (Posner 2001).

Moreover, according to these critics, Bork's teaching was read by antitrust agencies and the Supreme Court as an invitation to expand the reach of the defendantfriendly rule of reason, under which antitrust should prohibit only conduct that impairs efficiency and permit conduct that improves it (Khan and Vaheesan 2017). This has given currency to two dubious notions: one general, and the other platformspecific: First, the wealth transfer from consumers or suppliers to efficient trading partners with market power is a mere distributional concern that can be disregarded. Second, the $\mathrm{CW}$ standard is seen as establishing de facto antitrust immunity for online platforms that are characterized by nominally free goods and services, network effects, and economies of scale and scope.

This criticism is mistaken in two respects: First, it imagines a narrow ossification of so-called Chicago School thinking that is at odds with subsequent academic work. Nearly 20 years ago, for example, Posner (2001) expressed a far more nuanced view than that attributed to Bork:

Antitrust economists used to treat the transfer of wealth from consumer to monopoly producer as completely costless to society, on the theory that the loss to the consumer was exactly offset by the gain to the producer. The only cost of monopoly in that analysis was the loss in value resulting from substitution for the monopolized product, since the loss to the substituting consumers is not recouped by the monopolist or anyone else and is thus a net loss, rather than merely a transfer payment and therefore a mere bookkeeping entry on the social books. But the traditional analysis was shortsighted. It ignored the fact that an opportunity to obtain a lucrative transfer payment in the form of monopoly profits will attract real resources into efforts by sellers to monopolize and by consumers to avoid being charged monopoly prices (other than by switching to other products, the source of the cost of monopoly on which the conventional economic analysis of monopoly focused). The costs of the resources consumed in these endeavors are costs of monopoly

Thus, Posner (2001) concluded, "it is a reasonable guess that the total social costs of monopoly will usually exceed [the deadweight loss] by a significant amount". ${ }^{13}$ And subsequent, so-called post-Chicago scholarship has in fact had an enormous impact: Among other things, the more recent scholarship has developed a rich understanding

\footnotetext{
13 Posner's view on the large social costs of monopoly was already set out in a (1975) paper that can be found in the bibliography below.
} 
of how firms can harm competition by raising rivals' $\operatorname{costs}^{14}$ and how game theory can enhance our ability to understand bargaining both among rivals hoping to coordinate their behavior ${ }^{15}$ and between trading partners. ${ }^{16}$ Indeed, contemporary economic learning teaches that allocative efficiency-far from being confined to static welfare and reduction of deadweight loss-encompasses more broadly any improvement in the allocation of resources including through the innovation process. The teachings of post-Chicago scholarship have been brought to bear in contemporary cases. In its 2015 opinion McWane, Inc., v FTC, for example, the Court of Appeals for the 11th Circuit expressly quoted the seminal work of Krattenmaker and Salop on strategic anticompetitive exclusion in support of the holding that a dominant producer of domestic pipe fittings had used exclusive dealing arrangements to raise its "rivals' costs sufficiently to prevent them from growing into effective competitors" ${ }^{17}$

Second, this criticism fails to appreciate that Bork wrote about CW as the goal of the Sherman Act-not as being a legal rule that would itself determine the lawfulness of conduct (Werden 2014). Antitrust doctrine is embodied in a variety of legal principles that-while intended to promote economic welfare and susceptible of evaluation and revision in light of that objective - do not themselves require decision makers to base their determination in the particular case on a test of welfare effects. In this respect, antitrust is like other areas of the law. Patent law, for example, intends to promote innovation through the creation of incentives, and particular aspects of patent law can be evaluated by the extent to which they further that objective. But patent law does not require anyone to innovate, and the rules can be applied without regard to the effects of the individual case on innovation.

Recognizing that $\mathrm{CW}$ establishes a goal for antitrust law but not a legal rule enables one to appreciate, as will be seen below, that antitrust doctrine- the legal rules-is subject to evaluation and improvement in response to new commercial practices and in light of new learning about what kinds of rules might best further the $\mathrm{CW}$ objective. Through a common law-like process of incremental evolution, antitrust law has already departed in numerous ways from the particular notions that Bork and others shared 50 years ago. The Kodak opinion is a case in point: The Supreme Court reaffirmed the Jefferson Parish quasi per se prohibition of tying and rejected a number of early Chicago School views regarding the efficiencies of tying that had been embraced by Bork and others. ${ }^{18}$

It is simply wrong and a non-sequitur to say that, because Bork and other socalled Chicago School scholars were influential in the adoption of the CW standard, current antitrust doctrine is or needs to be limited by their understandings of

\footnotetext{
${ }^{14}$ Salop and Scheffman (1983), Krattenmaker and Salop (1986).

15 Tirole, The Theory of Industrial Organization, (1988) (in particular Chapter 6 "Dynamic Price Competition and Tacit Collusion").

${ }^{16}$ Hart et al. (1990).

${ }^{17}$ United States Court of Appeals for the Eleventh Circuit, McWane, Inc., v. Federal Trade Commission, No. 14-11363.

${ }^{18}$ Eastman Kodak Co. v. Image Technical Services, Inc. et al., 504 U.S. 451 (1992).
} 
economics in the $1960 \mathrm{~s}$. Contemporary CW-driven antitrust policy and doctrine are based in large part on Post-Chicago scholarship. ${ }^{19}$

\section{Price Fixation and Antitrust Reductionism}

The criticisms of the CW standard are misplaced, not just because they are based on a conceptual misunderstanding, but for other reasons as well. The specific operational or doctrinal criticisms are flawed on their own terms.

The CW standard is said to handicap antitrust doctrine in two concrete ways. It leads to:

(1) price fixation; and (2) antitrust reductionism under the false allure of scientific economics. Those problems are arguably compounded in an economy with widespread development of platform-based business models. We address these criticisms in turn and then briefly discuss the Supreme Court's recent platform decision in Ohio, et al. v. American Express Company ${ }^{20}$ as something of a case study.

\subsection{Price Fixation and the CW Blind Spots}

The price fixation argument is basically that $\mathrm{CW}$-driven antitrust leads decision makers to use a "narrow lens" (Wu 2018) and to focus analysis on short-term price or output effects. Critics of $\mathrm{CW}$ have suggested that this creates three blind spots when antitrust law is applied to platform markets (4.1.1.). But the problems that critics have identified are practical, not legal or conceptual; and abandoning the $\mathrm{CW}$ standard will not solve them (4.1.2).

\subsubsection{The Supposed Blind Spots: Innovation, Monopsony, and Zero-Price Markets}

Some critics of $\mathrm{CW}$ appear to believe that harm to innovation is not cognizable under the CW standard, where only effects on short-term prices or output matter. The concern is that, in today's information economy, dominant tech platforms can insulate themselves from competition by suppressing innovation by edge

\footnotetext{
19 See, for example, U.S. v. Dentsply Intern., Inc., 399 F.3d 181 (2005), in which the Third Circuit found that Dentsply, a dominant manufacturer of artificial teeth products, had unlawfully excluded competitors by threatening to withhold supplies should they sell rival product lines. The distributors were permitted to terminate their agreements with Dentsply "at will," and the agreements were in any event short-term contracts. The court nevertheless recognized that Dentsply could ensure the exclusivity of the distributors by its threat not to deal with those that handled competing products even if the distributors were not contractually bound to remain exclusive and thus held that Dentsply had violated Section 2 of the Sherman Act. See also Kodak case discussed above and McWane, Inc. v. F.T.C., No. 14- 11363, 2015 WL 1652200 , at *19 (11th Cir. Apr. 15, 2015).

20 Ohio v. American Express Co., 585 U.S. (2018).
} 
(non-platform) firms through non-price strategies such as applications cloning, ${ }^{21}$ shoot-out acquisitions, ${ }^{22,23}$

Other critics worry (along the same lines) that digital platforms can leverage their large datasets to discern consumer trends well before others and "quickly identify (and squelch) nascent competitive threats" (Stucke and Grunes 2016). Caves and Singer (2018) fear that the threat of strategic platform conduct may reduce entrepreneurship and innovation by reducing startups' access to venture capital. ${ }^{24}$ They argue that antitrust enforcers have almost given up challenging conduct or transactions on the basis of "pure innovation" based theories of harm.

Some critics also say that, under the CW standard, antitrust decision makers tend to "look down" rather than "up" when they examine platform based firm conduct (Ezrachi and Stucke 2017). The CW framework-including its explicit reference to consumers-directs antitrust decision makers to focus on the downstream consumer-facing sides of platforms and to disregard effects on sellers and providers on the upstream side.

Naidu et al. (2018) make a related yet distinct argument that the CW framework focuses analysis of antitrust injury on price increases that are caused by "product market power" and misses harm to workers that is caused by "labor market power". They advocate the addition of a welfare" standard alongside the "consumer welfare" standard, so as to catch conduct and transactions that increase labor market power.

The problems that stem from the consumer focus are exacerbated, critics say, when the platform supplies goods and services for free or low nominal prices on the consumer side (Rubinfeld and Gal 2016a). There is no antitrust enforcement because there appears to be no consumer harm, and dominant tech platforms are left free to exploit monopsony power in upstream or input markets like content (Stucke and Grunes 2016) and labor markets (Caves and Singer 2018).

The CW blind spot-if it is a blind spot-in the case of zero-price markets is a byproduct of economic tools that have been developed to implement the $\mathrm{CW}$

\footnotetext{
${ }^{21}$ The Economist, A lapse in concentration, September 29, 2016, from https://www.economist.com/ special-report/2016/09/29/a-lapse-in-concentration. For example, when Snapchat rebuffed Facebook's $\$ 3$ billion offer in 2013, the latter responded by imitating the app's most successful features. Dwoskin (2017) Facebook's willingness to copy rivals' apps seen as hurting innovation, Washington Post, Augustus 10, 2017, from https://wapo.st/2HGRuAN.

${ }^{22}$ This term refers to anticompetitive acquisitions of nascent potential rivals, The Economist, The world's most valuable resource is no longer oil, but data, May 6, 2017 from https://www.economist.com/ leaders/2017/05/06/the-worlds-most-valuable-resource-is-no-longer-oil-but-data and The Economist, Nostrums for rostrums, May 26, 2016, from https://www.economist.com/leaders/2016/05/26/nostrumsfor-rostrums. A recent paper characterizes these as "killer acquisitions." (Cunningham et al. 2018)

${ }^{23}$ Often, concerns are raised that integrated dominant platforms discriminate against third-party services by, among things, inhibiting access to those services. Concerns about such anticompetitive self-preferencing have been expressed with respect to search engines, OS, app stores, and digital content (Krämer et al. 2017).

${ }^{24}$ This concern is in some tension with the concern about shoot-out acquisitions, which are sometimes: (1) defended on the ground that they enhance exit opportunities for start-up investors and thus increase start-ups' access to venture capital; and (2) criticized on the ground that they induce excessive or misplaced investment in start-ups for the same reason.
} 
paradigm. It has become conventional in most antitrust proceedings to start analysis by defining relevant markets in which substitute products or services compete. Markets are commonly defined by observing or simulating the effects of a price increase; and where there are no prices, there is often no measurable market (Newman 2015). ${ }^{25}$ This problem is not inherent in the CW paradigm; and, as will be seen, it is not intractable either.

\subsubsection{The Problems are Practical, Not Legal or Conceptual}

The concern about CW's supposed blind spots in platform markets is misplaced. Let us start with the first and second blind spots: The idea that $\mathrm{CW}$-driven antitrust cannot address problems of platform innovation and monopsony power is wrong: both conceptually and as a matter of law.

Take innovation first. It is universally accepted that technological innovation improves both consumer and total welfare in many ways other than by increasing allocative efficiency and that the welfare benefits of innovation are in aggregate much greater than those from increasing allocative efficiency (Solow 1957). Conceptually-using the stylized supply and demand curves that are so common in antitrust analysis - the welfare improvements that result from technological innovation can be represented as rightward shifts in the demand (reflecting product improvements) and supply (refleting productive efficiencies) curves. The normative implications of such shifts are obvious: A firm that prevents rivals from effecting such shifts is able it to charge higher prices for existing products or services than otherwise, with a resulting reduction in output compared to the but-for world, and in that way can be said to have gained market power.

The cases recognize this, for they have long emphasized the very dynamic, nonprice harms with which CW critics are concerned. At least as early as Judge Hand's seminal 1945 decision in United States v. Aluminum Co. of America, antitrust law has been keenly interested in dynamic competition, entrepreneurship, and entry. ${ }^{26}$ And cases that were decided after the triumph of the CW paradigm in the late $1970 \mathrm{~s}$ or early $1980 \mathrm{~s}$ are to the same effect. In U.S. v. Microsoft Corporation, for example, the court condemned practices — unrelated to price - that threatened to raise entry barriers and thus to reduce or delay innovation. ${ }^{27}$

\footnotetext{
${ }^{25}$ Multi-sided platforms—such as Google's search engine or Facebook's social network—often give away products or services for "free" to users on the "subsidy side" in order to increase the value of the platform to advertisers that benefit from indirect network effects on the "money side" and thus the revenues that the platform can obtain from those advertisers. Users do not pay to interact with the platform; advertisers on the other side do.

${ }^{26}$ United States v. Aluminum Co. of America, 148 F.2d 416 (2d Cir. 1945), The court held that Alcoa had unlawfully prevented new entry and articulated the concern about monopoly power by noting that "possession of unchallenged economic power deadens initiative, discourages thrift and depresses energy; that immunity from competition is a narcotic, and rivalry is a stimulant, to industrial progress; that the spur of constant stress is necessary to counteract an inevitable disposition to let well enough alone".

${ }^{27}$ United States v Microsoft Corp., 253 F.3d 34 (D.C. Cir. 2001) (en banc).
} 
The same is true of monopsony power. As a conceptual matter, monopsony power is the mirror image of monopoly power (Lerner 1934). Deadweight loss, wealth transfer, and perverse incentives in seller markets are parallel to those in buyer markets. If $\mathrm{CW}$ is understood as total welfare or trading partner welfare, it encompasses buy-side or monopsony issues to the same extent as sell-side or monopoly issues (Hemphill and Rose 2018).

And the case law reflects the application of antitrust law in just that way (Werden 2007). ${ }^{28}$ In U.S. v. Adobe Systems, Inc., et al. for example, the Justice Department prosecuted a series of bilateral agreements amongst several large technology firms - including Google, Apple, Intel, Pixar, Intuit, and Adobe-that had allegedly agreed to refrain from soliciting, cold calling, recruiting, or otherwise competing for each other's computer engineers and scientists. The Justice Department noted that in a "well-functioning labor market, employers compete to attract the most valuable talent for their needs". And it regarded the agreement as facially anticompetitive because it "disrupted the normal price setting mechanisms that apply in the labor setting". ${ }^{29}$ The Justice Department has also challenged mergers on the ground that they would injure competition in buy-side markets. ${ }^{30}$

So, one might ask, why the controversy over CW? The answer is that successful challenges to pure innovation harms and monopsony power have been rare. The problem, however, is not legal or conceptual. It is practical. Like all decision-makers, antitrust agencies and courts are constrained in their ability to discover facts that are imperfectly observable (e.g., successful entry deterrence), measurable (e.g., product quality), or predictable (e.g., innovation and technological progress). Some data are easier to obtain, and some facts are easier to establish. So public and private antitrust enforcers have, for reason of prudence or pragmatism, focused on price and output effects.

Enforcers and courts do examine non-price effects and upstream markets, mindful that conduct can produce either injury or improvement, loss or benefit. Consider the FTC's 2013 decision to terminate its investigation against Google. The Commission explained that the search platform's "display of its own content could plausibly be viewed as an improvement in the overall quality of Google's search product".

\footnotetext{
${ }^{28}$ Noting that "the [supreme] Court's consistent interpretation of the Sherman Act, however, is wholly inconsistent with a narrow focus on end- user welfare".

29 See U.S. v. Adobe Systems, Inc., et al., Case No. 1:10-cv-01629, Complaint, September 24, 2010. Many private antitrust damage cases against buyer conspiracies have been settled after the courts denied motions to dismiss. S Seaman v. Duke University No. 1:2015cv00462 - Document 189 (M.D.N.C. 2018); Lindsay Kamakahi v. American Society for Reproductive Medicine, United States District Court, Northern District of Ca., Class Action Complaint, Case No. 3:11-CV-1781 (filed April 12, 2011); Allen v. Dairy Farmers of America, Inc., 16-1944 (2d Cir. 2017); During the 11-year period 1997-2006, the Department brought 70 criminal cases against buyer cartels. OECD, Roundtable on Monopsony and Buyer Power, 2008, Note by the US, DAF/COMP/WD(2008) 79.

30 E.g., United States v. Cargill, Inc. and Continental Grain Co., Civil No. 99-1875 (GK) (filed July 8, 1999). In its review of Anthem-Cigna, the DoJ refused to credit as efficiencies the merged entity's ability to reduce rates paid to doctors. The DC Circuit declined to rule on this. In a dissent, Judge Kavanaugh suggested that savings achieved through reduced rates paid to doctors ought to be viewed as procompetitive efficiencies. See United States v. Anthem, No. 17-5024 (DC Cir. 2017).
} 
And in Weyerhaeuser Co. v. Ross-Simmons Hardwood Lumber Co.-which was not a platform case-the Supreme Court rejected a claim of anticompetitive buy-side conduct: not on the ground that such conduct was beyond the reach of the antitrust laws, but because the plaintiff had failed to show that the conduct in question was anticompetitive. $^{31}$

Similarly, the criticism that current antitrust enforcement has not prevented innovation harm caused by shootout mergers has nothing to do with the $\mathrm{CW}$ standard. For one thing, many of those acquisitions are too small to meet the requirement for pre-merger notification. More important, those acquisitions might be pro-competitive for a number of reasons. They often-or even usually-provide a profit-maximizing exit opportunity for early investors in new and unproven technologies and are thus likely to promote investments in innovation. They can both enable small units with organic constraints to scale through external growth and enhance opportunities for socially efficient combination of complementary assets and the ability and incentives of purchasing incumbent platforms to innovate.

The acquisitions might, on the other hand, be harmful if they "nip in the bud" nascent or potential competition that would otherwise take place. The enforcement problem is a practical one: In platform markets, it is difficult to distinguish startup acquisitions that seek to extinguish an incipient competitive threat "from a situation in which the dominant incumbent can and will greatly expand the reach and usage of the target firm's products" (Shapiro 2017). Nothing about the CW standard prevents the law from incorporating different presumptions about the likely pro- and anti-competitive effects of such mergers based on different assessments of factual likelihoods or different attitudes about the relative risks of Type 1 and Type 2 errors.

The same can be said about the argument that antitrust law cannot adequately address anticompetitive conduct in "zero price" markets. The problems here are neither conceptual nor legal. For one thing, there is often less to "zero price" than meets the eye. First, the "zero price" is sometimes temporary, when the product or service is new or elementary (which is, incidentally, a common feature in intangible markets with beta and test versions). Antitrust law has ample experience with temporary low-price policies that are followed by price increases: such as loss leading, versioning, or two-part tariffs, some of which are ubiquitous on platform markets.

Second, there is less of a dichotomy between "zeroprice" services and others than the rhetoric suggests. "Zero price" refers to the nominal monetary price that is charged by the seller for services that the customer pays back with a non-monetary contribution, and a zero monetary price is not always the same as "free." In platform markets, for example — such as search and social networking-the user transfers valuable resources to the platform: time, attention, and personal data (search queries, social graph, sentiment information). In principle, therefore, antitrust decision makers could estimate the total monetary and non-monetary price

${ }_{31}$ Weyerhaeuser Co. v. Ross-Simmons Hardwood Lumber Co., 549 U.S. 312 (2007). 
and analyze the market similar to any other. ${ }^{32}$ Estimating the non-money price is, however, likely to be very difficult as a practical matter.

Third, sustained zeroprice markets are typically one side of a multi-sided market or platform in which the seller generates revenue from other sides. Obvious examples include broadcast television, "free" shoppers or other newspapers, and a multitude of online services, such as those that are offered by Google or Facebook. And, as will be seen in the discussion below of the American Express case, no changes to the $\mathrm{CW}$ standard are required in order for antitrust law sensibly to address issues that are raised by multi-sided markets or platforms.

Still, zero price markets do sometimes present new challenges. Among other things, they can induce customer lock-in and distort competition in complementary markets, and they require decision makers to use tools other than analyses of pricing data to define markets and assess market power. These challenges are usually not insurmountable. The competitive harm that might be caused in zeroprice markets is almost always the result of more complex conduct that involves positive prices at some point, bundling or tying with positive-priced goods, or nonprice conduct and that can be assessed by traditional antitrust tools (Rubinfeld and Gal 2016a). And markets and market power are commonly assessed without reliance on pricing data. In the Microsoft case, for example, the government was able to define a market and demonstrate that Microsoft had monopoly power in that market without relying on price data and, in fact, over Microsoft's argument that its low prices demonstrated that it lacked market power.

The CW standard, in short, presents no conceptual or legal obstacle to addressing issues that involve innovation, monopsony, and zeroprice markets. The "blind spot" criticisms of the CW standard thus need to be based on pragmatism rather than principle. The argument might be as follows: "Even if CW works in theory, as it has been applied, it requires factual and economic understanding that is often impractical. It should thus be replaced with a standard that is less difficult to apply."

We do not quarrel with the first sentence, but the second is a non-sequitur. For one thing, the practical problems are likely to be less serious in the future. Antitrust academics-lawyers and economists-have, for example, developed various formal and empirical tools, such as those described in the agencies' merger guidelines for defining markets as a proxy for measuring market power. They are now turning their attention to the new issues that are raised by dynamic markets characterized by winner-takes-all competition, multi-sided platforms, network effects, and often the

\footnotetext{
32 In attention markets where platforms monetize personal data by supplying online advertising, for example, the amount that the platform operator would be willing to pay for the data should be situated somewhere between: (1) the average revenue per user ("ARPU") that is generated by the platform in transactions with advertisers; and (2) the marginal cost of acquiring, curating, processing and protecting personal data. A concrete example is helpful to drive this point home: In 2017, Facebook reported in its $10 \mathrm{~K}$ a worldwide ARPU of $\$ 20.21$, a daily user base of 1.40 billion, and a total cost of revenue of $\$ 5.54$ billion. A back-of-the-envelope calculation suggests an average variable cost for Facebook-a proxy for marginal cost—of $\$ 3.96$. This suggests that the "privacy adjusted" subscription fee to the Facebook platform (yearly) included data that were valued by Facebook at not more than $\$ 16.25$.
} 
utilization of big data and the provision of services for a zero nominal price-which are rapidly replacing yesterday's static and slowly evolving markets (Katz and Sallet 2018; Rubinfeld and Gal 2016b). One can reasonably expect the development of new tools that will reduce the practical problems that are posed by antitrust enforcement in the information economy.

Moreover, critics complain that antitrust law is too humble and that it defaults to non-enforcement when faced with factual or economic uncertainty-often by concluding that the complainant has not proven that the alleged conduct was anticompetitive or harmed competition. Whether the substantive, default, and burdenof-proof rules are optimal in some or all cases is a fair subject for debate. The important point for present purposes is that nothing in the $\mathrm{CW}$ paradigm prevents revising those rules.

As we previously noted, antitrust doctrine evolves through a common law process "as circumstances change and learning grows" (Easterbrook 1982). Antitrust law can and does replace rules that do not reflect sound analysis, as it has done, for example, with safe harbors for exclusive dealing that covers less than a specified percentage of the market ${ }^{33}$ or that is not implemented in long-term contracts. ${ }^{34}$ And it can replace rules that require detailed factual assessment of individual cases with simpler, more categorical rules, such as: the per se prohibition of price fixing; the modified per se rule that is applicable to most tying arrangements under Jefferson Parish; presumptions such as those used in horizontal merger analysis; a greater willingness to find a violation on the basis of likely effects, especially where actual competitive effects are difficult to observe or measure; and abbreviated ruleof-reason standards that permit an inference of harm to competition under some circumstances without proof of actual harm to competition.

While antitrust law has moved away from such simplified rules in recent years, there is nothing about the $\mathrm{CW}$ paradigm that would preclude a movement of the pendulum in the other direction: either in response to new understandings about factual and economic issues, or in response to a revised assessment of the likelihood and costs of Type 1 and Type 2 errors in general or with respect to platforms or other specific matters.

\subsection{Antitrust Reductionism}

$\mathrm{CW}$ is often described as a byproduct of "economism" in antitrust policy. The idea is that economic analysis leads to a reduced role of the State in the correction of market failures (Fox and Sullivan 1987; Khan and Vaheesan 2017). This criticism has two variants: Some argue that the $\mathrm{CW}$ paradigm has created complexity because it has caused antitrust to be focused on matters of economic welfare and applied economics that often involve difficult and sophisticated problems (Wu 2018). Khan (2017) states that this is clearly the case in platform markets: "Economists tend to conclude

33 E.g., United States v. Microsoft Corp., 253 F.3d 34 (D.C. Cir. 2001).

34 E.g., Dentsply International, Inc. v. United States, 399 F.3d 181 (3d Ir. 2005). 
that_-given the particular challenges of two-sided markets-antitrust should be forgiving of conduct that might otherwise be characterized as anticompetitive". 35

Others suggest that the CW standard has overly simplified antitrust law (Leslie 2014; Vaheesan 2018) and has thereby given rise to widespread reliance on defendant-friendly theories that accept and legitimize conduct in antitrust law application and policy formulation. The result, again, is less antitrust enforcement.

Both criticisms confuse specific applications of the $\mathrm{CW}$ standard with inherent properties or implications of the standard. The $\mathrm{CW}$ standard sets forth economic criteria for guiding antitrust doctrine. The standard can encompass both expansive and restrictive antitrust policy, depending on empirical judgments (e.g., how likely will entry dissipate a market-power problem and over what time period) and judgments about how to deal with uncertainty (e.g., how much proof do we require before we are willing to conclude that prices were below cost, and are we more concerned about false positives or false negatives).

The CW standard does increase the importance of economic analysis in antitrust law; but economic analysis does not inherently bias enforcement in a more or less interventionist direction. While economics does demonstrate that common intuitions are often incorrect (e.g., the idea that RPM categorically harms consumers) and in that way can sometimes nudge the law in a more conservative direction, economics can also be used to imagine all sorts of anticompetitive strategies, private market failures, and remedies for them. New ideas in antitrust economics have encouraged increased enforcement in the past (Krattenmaker and Salop 1986; Salinger 1988) and may well do so with respect to a variety of current issues as well (Elhauge 2016; Federico et al. 2018).

A comparison of U.S. and EU competition enforcement illustrates how enforcers can reach different outcomes even when they share a commitment to the $\mathrm{CW}$ standard, over which there is broad convergence in merger and coordinated conduct cases (Kovacic 2008). In Microsoft/LinkedIn, for example, the European Commission was concerned about the risks of post-merger marginalization of competing professional social networks that offered "a greater degree of privacy protection to users than LinkedIn" and held that the merger would cause "harm to consumers" and "restrict consumer choice". And in other cases involving digital platforms, European competition agencies have objected to MFN clauses that are used by online travel agents in contracts with hotels on the ground that they foreclose competitive entry and/or expansion and inflict net losses to consumers.

U.S. enforcers reached different conclusions in these matters because they made different assessments of the effect of the conduct on consumer welfare. The more cautious U.S. approach appears to reflect a greater aversion to the risk of Type 1 errors. $^{36}$

\footnotetext{
$35 \mathrm{Wu}(2018)$ argues that $\mathrm{CW}$ "has led enforcers to place an emphasis on price-fixing cases or horizontal mergers that can be shown to have clear price effects over more complex but potentially much more important cases.".

${ }^{36}$ See OECD hearing on Across Platform Parity Agreements, Note by the US, DAF/COMP/WD (2015) 72.
} 
The differences are not attributable to the CW standard in U.S. antitrust law because the European agencies rely generally on the same standard. In fact, the EU statutory provision on anticompetitive unilateral conduct is almost entirely phrased in terms that are closely related to the CW standard (Joliet 1970). The differences between EU and US enforcement reflect different factual judgments within the CW standard about such matters as the likelihood of future harm and the likely efficiencies from the conduct at issue and different normative judgments about the relative importance of Type 1 and Type 2 errors or preference for total welfare or trading partner welfare (Blair and Sokol 2013).

Differences in decisional outcomes under the CW standard might also be attributable in part to institutional and procedural differences. In the EU, agency decisions are self-enforcing, presumptively lawful and subject to a Chevron-type judicial deference standard; and defendants are not permitted to take discovery from third parties or to cross-examine adverse witnesses. In the US, by contrast, most antitrust cases are litigated in independent tribunals; all are subject to review by courts that decide questions of law de novo; and defendants are permitted to take discovery from third parties and to cross-examine adverse witnesses. In these respects, US law is more defendant-friendly, and EU law is more likely to entail false positives. Again, however, these differences have nothing to do with the CW standard.

\subsection{Lessons from the American Express Case}

The American Express litigation that culminated in the recent Supreme Court decision in Ohio, et al. v. American Express Company ${ }^{37}$ is the only US antitrust case that expressly addressed issues that are uniquely raised by platforms and multisided markets and is thus an important illustration of the CW standard at work. Critics of the CW standard - as well as many supporters of the CW standard-are unhappy with the Supreme Court's decision. They are concerned that - if read broadly and because of its skepticism that vertical agreements can injure competition and its approach to market definition - the decision might largely insulate certain activities by platform businesses from effective antitrust discipline. These could include potentially anticompetitive restraints, such as: exclusive dealing; Most Favored Nation ("MFN") clauses; and best-price policies. ${ }^{38}$

Let us look more closely at the American Express case. It concerned the lawfulness of Amex's so-called "no-steering" rules: These essentially prevented merchants that accepted Amex cards from, among other things, charging consumers lower prices (for goods or services) when the latter used other cards that charged a lower fee to merchants. The plaintiffs argued that the rules restricted competition and entry by reducing the ability of competing card issuers to increase sales by charging lower fees to merchants. Amex argued that the rules were necessary to protect its cardholder goodwill and to enable it to fund its more substantial cardholder rewards

37 Ohio, et al. v. American Express Company, 585 U.S. (2018).

38 See, e.g., Khan (2018a, b, c) and Singer (2018). 
programs and thus to compete by differentiating its products from the Visa and MasterCard alternatives.

It is not clear from the Supreme Court opinions whether Amex did or did not violate the antitrust laws. It is clear, however, that the majority made a number of serious mistakes: In all of them, the Court analyzed the issues too abstractly and formalistically and did not directly address important facts found by the district court or the material factual questions: whether the no-steering rules were in whole or part not efficiency-based competition on the merits; and whether they diminished the competitive efficacy of American Express' competitors. As will be seen, those mistakes reflect a misapplication of the $\mathrm{CW}$ standard-not limitations that are required by or inherent in the standard.

First, the Court held that defining a relevant market is necessary in order to conclude that a vertical restraint is anticompetitive and that direct proof of anticompetitive effects is insufficient. This holding is wrong as a matter of both law and economics: As to the law, the Court distinguished cases holding that market definition is not necessary with respect to horizontal agreements on the ground that "vertical agreements often pose no risk to competition" and cited a 1984 law review article by Professor Frank Easterbrook. ${ }^{39}$ But horizontal agreements, too, often pose no risk to competition ${ }^{40}$; and the very passage from the Easterbrook article quoted by the Court says only that it is necessary to find "market power", not that it is necessary to define a relevant market.

As to the economics, suppose: that some states at various times had rules that prohibit American Express from applying no-steering clauses to in-state merchants; that the evidence convincingly showed that, when those laws were in effect, there were more credit card transactions at either higher value to merchants and/or lower costs to cardholders (taking into account fees, prices, cardholder rewards, and other quality-related features) in those states (1) than at other times and (2) relative to other states; and that there was no apparent explanation for the differences other than the enforceability of the no-steering clauses. If those were the facts, there would be no need to require proof of a market in order to conclude that the no-steering clauses were anticompetitive.

Nothing about the CW standard required the Court to make this mistake, as Justice Breyer's lengthy dissent plainly demonstrates. The Court erred: not in requiring proof of harm to competition, but in misunderstanding what that proof requires.

Second, the Court held that, in what it called a "two-sided transaction platform," in which the platform facilitates a "simultaneous transaction between participants," the relevant market must include both sides. The analysis here was largely formalistic. The Court reasoned that, in matters involving a transaction platform, both sides are simultaneously implicated in each transaction and there can be effects on one

\footnotetext{
39 See Amex Opinion at footnote 7, citing Easterbrook, Vertical Arrangements and the Rule of Reason, 53 Antitrust L. J. 135, 160 (1984).

${ }^{40}$ For an example, see Broadcast Music, Inc. v. CBS, Inc., 441 U.S. 1 (1979); FTC/DoJ Antitrust Guidelines for Collaboration among Competitors, 2000 at footnote 26 ("That market power is absent may be determined without defining a relevant market").
} 
side from a transaction on the other; therefore, both sides need to be included in the market. A platform such as Facebook, for example, is different because the response of the Facebook user to online advertising comes, if at all, later and outside of the platform.

The Court correctly noted that both sides of the platform needed to be considered; but it was not necessary to include both sides in a single market. The Court was trying to determine whether Amex had the ability_market power over merchants- to injure competition in a properly defined credit card market. That question can be answered by defining a market on the merchant side only and taking effects on the cardholder side into account as part of the factual context. ${ }^{41}$ This can be seen, for example, by imagining a merger case in which a market is being defined by application of the standard SSNIP test as described in the U.S. agencies' merger guidelines. To begin, assume that, if a monopolist on the hypothetical credit card market on the merchant side increased the merchant fee, some merchants would drop the card, but not enough so as to cause the price increase to be unprofitable. Assume further that the reduction in the number of merchants that accepted the card would cause a reduction in the number of card holders. If the combination of the loss of some merchants and the reduction in the number of card holders would cause the increase in the merchant fee to be unprofitable, we can conclude that the hypothetical merchantside market is not an antitrust market, and vice versa.

Including both sides in the same market is not only unnecessary, but also can be problematic. In the first place, it makes almost meaningless the idea of market shares, which if used properly can help assess a firm's importance in the market. What is the market share of a firm that has a $60 \%$ share on one side and only a $15 \%$ share on the other if both are included in the same market?

Including both sides can also introduce needless complexity into the process of defining a market. Market definition focuses on demand substitution: identifying the alternative sellers that are available to buyers and constrain one another's behavior. ${ }^{42}$ Markets are typically defined by, in effect, imagining concentric circles that bound the alternatives that are available to the buyers that might constrain the exercise of market power by the subject firm, which in this case was Amex. The decision maker searches for the smallest circle that has the properties of an antitrust market. She might, for example, ask whether American Express cards are themselves a market; if they are not, she would move to the next closest substitutes, maybe Visa and MasterCard; and, if they are not a market, she would add to the possible market the next closest substitute, maybe Discover cards; and so on.

For most platforms, however, the competitive constraints are not same on both sides. Take newspapers, for example: A reader's alternatives to the newspaper might include television news, local shoppers, and so on; but most advertisers

\footnotetext{
41 See CJEU, Case C-67/13 P, Groupement des cartes bancaires (CB) $v$ European Commission, ECLI:EU:C:2014:2204, $\$ 77$ (criticizing the lower court that had "confused the issue of the definition of the relevant market and that of the context which must be taken into account in order to ascertain whether the content of an agreement or a decision by an association of undertakings reveals the existence of a restriction of competition 'by object' within the meaning of Article 81(1) EC'.).

42 U.S. Department of Justice and Federal Trade Commission, Horizontal Merger Guidelines $§ 4$ (2010).
} 
will not regard all of those alternatives as suitable substitutes. By the same token, advertisers might consider alternatives, such as billboards, that readers would not regard as substitutes for newspapers. And even when the competitors are the same on both sides, competitive conditions might be very different (Hemphill and Rose 2018).

Including both sides in the same market would require determining which combinations of possibly very different competitive alternatives on both sides, including alternatives on one side that are not meaningful alternatives to buyers on the other side, would constitute a market. If, as in a newspaper case, one is concerned about alleged constraints on competition on the reader side, there is no need to determine which of the possible constraints on the advertiser side might be deemed to be "in the market;" it is sufficient to determine whether feedback effects from the advertiser side as a whole would prevent the exercise of market power in the alleged market on the reader side.

The Court acknowledged that not all two-sided platforms involve a single market, ${ }^{43}$ and its rationale for finding a single market in the Amex case would seem to be applicable to only a narrow subset of two-sided platforms. By focusing on "twosided transaction platforms" rather than platforms in general, the Court might have intended to limit its analysis to cases in which the competitors in the market are the same on both sides. If so, its analysis says little about market definition for platforms in general and raises the question why a special legal rule is needed for a small subset of platforms.

Moreover, it is not clear that the competitors are the same on both sides even in "transaction platforms." For example, Uber would probably fit the Court's definition of a "transaction platform;" but the alternatives on the two sides are not the same. Users' alternatives - Lyft, taxis, public transportation, bikes, scooters, walking — are more diverse than drivers' alternatives: other ride-hailing platforms, such as Lyft, or maybe food-delivery services.

Even for Amex, it is not clear that the competitive constraints are the same on both sides. The Court noted that almost all cardholders carry both Visa or MasterCard and thus do not need Amex but that many merchants are reluctant to give up Amex because of its unique signaling value for the narrow, upscale demographic at which it is aimed. ${ }^{44}$

A rule that both sides must be included in the relevant market if the competitors in the market are the same on both sides would thus require, even for a transaction market, an antitrust decision maker: first, to determine the universe of competitive

\footnotetext{
43 "To be sure, it is not always necessary to consider both sides of a two-sided platform. A market should be treated as one sided when the impacts of indirect network effects and relative pricing in that market are minor".

44 The Court stated that "only other two-sided platforms can compete with a two-sided platform for transactions." Unless the word "transactions" is intended to refer to two-sided transaction and thus to render the sentence tautological, the statement is not correct. Credit card platforms, for example, compete against cash and travelers' checks as means of funding purchase transactions for goods and services. Whether cash and travelers' checks should be included in the market is an empirical question that cannot be answered by characterizing Amex's business as a "transaction platform".
} 
constraints separately for each side of the platform-in effect, to define a market separately for each side; and then, if the firms in the market are identical on both sides, to analyze a different market that encompasses both sides. As explained above, there is no need for such contortions in order to answer the substantive issues of market power or competitive effects.

Combining both sides in a single market creates another problem as well. It greatly complicates the task of assessing injury to competition when, as in cases like Microsoft ${ }^{45}$ and Lorain Journal, ${ }^{46}$ the injury is manifest on only one side of the platform. Even if, as in those cases, there are no cognizable countervailing benefits on the other side of the platform, defining a single market on both sides would require courts and litigants to grapple with the question whether competition is injured in the two-sided market as a whole. ${ }^{47}$ The result will be not only needless complexity in antitrust cases but also a likely bias toward false negatives. ${ }^{48}$

The problem goes beyond complexity. The effect of defining a single market on both sides, according the Court, is that the plaintiff, which is charged with proving injury to competition in the market as a whole, must prove that harms on one side - in this case, higher merchant discount fees-are not fully offset by benefits on the other side-in this case, improved cardholder services or rewards and increased cardholder goodwill. It thus puts on the plaintiff a burden of proving a negative and of doing so on a topic with respect to which the defendant will almost always have better access to evidence. Accurate fact-finding is best served when parties are not required to prove negatives and when the party with the best access to evidence has the burden of proof. This burden-shifting feature of the Court's market definition appears to have been outcome-determinative in the Amex case.

Again, nothing about the CW standard required the Court to take this needlessly confounding approach to market definition. The Court erred by relying on a formalistic analysis instead of engaging in a substantive application of the $\mathrm{CW}$ standard.

Third, the Court analyzed the allegedly unlawful conduct at too high a level of abstraction. The ultimate issue in the case was whether the no-steering rules injured competition by reducing the ability of Discover, Visa, and MasterCard to compete and grow by offering merchants low prices. The Court noted that credit card transactions had increased and that Amex's merchant fees had been constrained by

\footnotetext{
45 United States v Microsoft Corp., 253 F.3d 34 (D.D. Cir. 2001) (en banc).

46 Lorain Journal Co. v. United States, 342 U.S. 143 (1951).

47 We assume for present purposes that, even if separate markets are defined on each side of the platform, benefits on one side should be weighed against harms on the other side to determine whether the conduct injured competition. The alternatives would be to take those benefits into account only to the extent that feedback effects cause them to offset the harm on the other side (e.g., benefits to Amex card holders from the no-steering rules might benefit merchants by increasing retail sales) or to ignore them altogether. Antitrust law generally does not balance harms and benefits in different markets because, among other things, the competitors, trading partners, market structures, and nature of competition are often very different and there is often not a common metric (Katz and Sallet 2018).

${ }^{48}$ Not surprisingly, the Court's approach to market definition in multi-sided platform environments has garnered support from antitrust scholars more concerned with the avoidance of false positives. Bork and Sidak (2012), for example, advocated a similar approach for Internet search engines, even though those platforms do not fall within the concept of a "transaction platform" as defined by the Supreme Court.
} 
competition with other networks, but the Court did not address whether transaction volume would have been greater and merchant fees lower absent the no steering rules. The Court erred by looking only at the credit card industry when the no-steering rules were in effect, instead of comparing that world to an otherwise identical but-for world in the absence of those rules.

More generally, the Court did not address the findings of the district court about the impact of the no steering rules on competition among credit cards. These included findings that the no steering rules lessened the incentives of Amex and other credit cards to reduce price, effectively prevented Discover from competing by offering merchants a lower-priced card, and thereby enabled Amex to charge higher merchant fees than otherwise without losing merchants or increasing cardholder rewards.

Similarly, the Court emphasized that the no-steering rules addressed what it called an externality from possible free-riding by merchants; but the Court did not inquire into either the extent to which investments by Amex actually increased merchants' sales, rather than just Amex' share of those sales, or whether there were less restrictive means to address the free-riding problem. ${ }^{49}$ Moreover, the Court ignored entirely the very different externality that is created by the no-steering rules: The rules prohibited merchants from passing on specifically to users of Amex cards the higher merchant fee costs of Amex transactions and thus induced merchants to take those costs into account when setting the merchandise prices charged to all customers-including users of competing credit cards ${ }^{50}$ In effect, the no-steering rules required users of less expensive cards to subsidize American Express cards and removed any incentive cardholders would otherwise have to take the cost of using the Amex card into account when deciding whether to use it. As a result, the district court found, merchant fees for all credit cards and consumer prices were higher than they would have been absent the no steering rules.

Nothing about the $\mathrm{CW}$ standard prevented the Court from engaging with the facts in a more granular way.

Some critics (Khan 2018a, b, c) think that the lesson of the American Express case is that generalist judges should not be asked to decide matters that involve "complex economic analysis." If that is the right lesson to draw, antitrust law could

\footnotetext{
${ }^{49}$ The alleged free-riding would occur if a merchant induced a customer to shop at the store because it accepted Amex cards and then induced the customer use a different card. Possible alternatives would be a rule that barred steering only when the merchant advertised that it accepts Amex cards or one that permitted steering to the extent that it simply entailed offering different prices to consumers to reflect the differences in the merchant fees depending on which card the consumer used. Indeed, it is far from clear that requiring Amex users to pay the additional costs of their cards can properly be regarded as free-riding, any more than one would regard as free-riding a store taking different wholesale merchandise costs into account in setting different retail prices for different products.

${ }^{50}$ If, for example, the merchant offered to pass on to the consumer a portion of the savings from lower merchant fees that are charged by a different card system, both the consumer and the merchant would benefit from the lower fees. The competing card system would benefit as well and would have an increased incentive to reduce its prices. American Express would lose revenues that it claimed were needed to fund cardholder rewards, but it would lose those revenues only to the extent that consumers chose not to pay even a portion of the higher fees in order to get the rewards.
} 
address the problem by adopting per se rules and the like that do not require "complex economic analysis" for their application. As discussed above, that move would not require or be enhanced by abandoning the $\mathrm{CW}$ goal.

\section{Competitive Process, “No Fault" Antitrust, and Conduct-Based Rules}

Many of the critics of $\mathrm{CW}$ have in mind an alternative to the $\mathrm{CW}$ standard for antitrust policy: "protection of competition" or the "competitive process" (Khan 2017; $\mathrm{Wu}$ 2018). The words themselves to do not necessarily imply a departure from the CW standard because, as was explained above, both of the key elements of existing US antitrust law-anticompetitive conduct, and increased market power-are focused on harm to the competitive process. The courts have recognized this connection as well. ${ }^{51}$

The critics are often unclear about the concrete elements of antitrust liability that would operationalize a "protection of competition" policy in relation to platformbased firms, but their remedy proposals enable us to draw inferences about their preferred antitrust doctrine. The core idea seems to be the removal of one of the three elements of a violation of antitrust law: bad conduct, market power, and a causal link between them. There are two variants to this idea:

Some CW critics want to decrease the importance of the "bad conduct" element, so as to migrate towards a more "no fault" antitrust intervention on the basis of a showing of a situation of "structural dominance" (Khan 2017). Others would retain the conduct requirement and dispense with the market power screen. Both proposals are unsound.

\subsection{No-Fault Antitrust for Platforms}

Some critics of CW display sympathy for a "no fault" antitrust or something very close to this (Khan 2017; Woodcock 2017). ${ }^{52}$ In this alternative framework, the bad conduct requirement that is necessary to establish antitrust liability-in Section 1 cases, concerted action; in Section 2 cases, exclusionary conduct-is either removed or marginalized (for example, through greater reliance on incipiency theories in antitrust doctrine or the concept of "special responsibility" of dominant firms that is used in the EU). ${ }^{53}$ Instead, a market power screen of some sort would be used to identify a position of "structural dominance" that provides the basis for antitrust

\footnotetext{
51 E.g., National Society of Professional Engineers v. United States, 435 U.S. 679 (1978).

52 This point is well explained in First (2018).

53 The issue of no-fault antitrust seems unrelated to merger enforcement. Merger law prohibits mergers that are deemed to be anticompetitive. Changing the proof required and presumptions used to determine whether a merger is anticompetitive would change the definition of the prohibited conduct and would be unrelated to moving to a no-fault antitrust law.
} 
intervention. In effect, these critics seem to be saying, the law should give less deference to efficiency and should focus more on rivalry.

The normative idea is that society is better off when more than one platform, and/or related upstream and downstream businesses, operate in a market. When this condition is not met, the concentrated structure of the platform market creates anticompetitive conflicts of interests and perverse behavioral incentives, such as discrimination and leveraging (Khan 2017). ${ }^{54}$ The promotion of inter- and intra-platform rivalry would require the imposition of positive obligations-e.g., must-carry requirements, mandatory API sharing, data portability measures-on platformbased firms. It might also require heightened M\&A restrictions and possible divestitures that are aimed at eliminating structural dominance.

A no-fault antitrust law would almost certainly inflict static welfare losses on society. To start, breaking up platforms horizontally would likely reduce productive efficiencies, require replication of fixed costs not fully utilized and thereby increase average total costs, and reduce the benefits of network effects on the various sides of the platform. Moreover, when improperly executed-which is a non-trivial possibility-a platform break-up might give rise to negative network externalities, transaction costs, and excessive platform fragmentation.

To capture this intuition, we invite readers to travel back to the world of Internet search before 2000, when users searched web pages through multiple platforms and then had to compare search results. The upshot was lost time for users and costly campaigns for advertisers.

Breaking up vertically integrated companies or those providing complements could also reduce static efficiency.

Productive efficiency could be harmed by diseconomies of scope and lost spillovers. And allocative inefficiency might result from the increased potential for double marginalization, which would lead to increased prices and reduced output. Similar but perhaps less substantial welfare losses would result from conduct restrictions that limited the ability of platforms to take full advantage of whatever efficiencies are created by their size and scope.

A no-fault antitrust law would also have dynamic costs: By reducing the rewards to "skill, foresight and industry", as the court put it in Alcoa, the law would reduce the incentives for and thus the likely investment in such productive endeavors. ${ }^{55}$ And by offering the prospect of antitrust intervention to assist rivals and complementors, no-fault antitrust law could reduce their incentives to innovate and otherwise compete vigorously in order to flourish without such aid. Such a law would also require on-going industry monitoring. If, for example, there are strong network effects in

\footnotetext{
54 Khan (2017): 'Rather than pegging competition to a narrow set of outcomes, this approach would examine the competitive process itself. Animating this framework is the idea that a company's power and the potential anticompetitive nature of that power cannot be fully understood without looking to the structure of a business and the structural role it plays in markets. Applying this idea involves, for example, assessing whether a company's structure creates certain anticompetitive conflicts of interest; whether it can cross-leverage market advantages across distinct lines of business; and whether the structure of the market incentivizes and permits predatory conduct".

55 See United States v. Alcoa, 148 F.2d 416.
} 
a market, there are likely to be recurring monopolies as markets tip to one rival or another.

On the other hand, no-fault antitrust law could promote economic welfare by reducing the deadweight loss that results from enduring market power and by facilitating the entry of rivals and complementors and thus inducing investment in such rivals. Whether no-fault antitrust law would on balance increase or decrease welfare is an empirical question, and the answer might differ depending on the industry or even the specific company. In the platform world, for example, Amazon seems to have large fixed costs (for example, those related to its fulfillment infrastructure), while platforms such as Facebook and Google have relatively lower fixed costs and higher variable costs (for example, those that are related to labor-intensive content moderation); but the latter probably provide greater network efficiencies.

U.S. antitrust law takes a clear stand on this issue: No antitrust violation is found, and no antitrust remedy is warranted, unless the defendant has engaged in anticompetitive conduct: conduct that does not increase efficiency but does tend to increase market power by coordinating the conduct of competitors or weakening or excluding competitors. ${ }^{56}$ The stand seems to reflect both a normative judgment-if you play by the rules, you can enjoy the fruits of success - and a crude empirical judgment that the welfare costs of no-fault intervention exceed the benefits as a general matter and trying to carve out the exceptional case would be too difficult or costly.

The CW standard does not require antitrust law to be based on either that normative judgment or that empirical judgment. Certainly, those have not been the premises of EU competition law, at least until recently. Several leading EU cases declared that dominant firms are under a "special responsibility" that was often understood, for example, to imply access and nondiscrimination obligations. ${ }^{57}$ Even today, EU competition law guidelines make clear that stricter standards apply where inaction would leave only a single firm in the relevant market. ${ }^{58}$ The idea is that preserving access by outsiders, small firms, and less efficient upstarts, and ensuring that some competitors remain in the market, would promote welfare over the long run (Fox 2008a, b).

The EU seems to be moving away from this kind of no-fault competition law, not because the $\mathrm{CW}$ standard compels such a move but for other, more pragmatic reasons that arise from the difficulty of determining when and how to intervene in a nofault system. How should the law define threshold levels of platform monopoly that warrant antitrust intervention? How should it account for the welfare costs of intervention? Are some markets or firms too valuable or too innovative for government intervention, even if concentrated or powerful? Are some remedies too disruptive

\footnotetext{
56 Complexities and subtleties can arise with some kinds of conduct that both increases efficiency and weakens or excludes rivals, but those complications are not material to the issues that are addressed in this paper.

57 Regardless of an effective analysis of the economic justifications for their conduct (including that its conduct is an essential feature of competition). Among others, see CJEU, Case 85/76, Hoffmann-La Roche v Commission, ECLI:EU:C:1979:36, \$\$107 and 123.

58 Guidance Communication on the Commission's enforcement Priorities in Applying Article 82 of the EC Treaty to Abusive Exclusionary Conduct by Dominant Undertakings, OJ C 45 2009, 7-20.
} 
and costly? The $\mathrm{CW}$ critics that sympathize with a migration of antitrust towards a no-fault approach have not addressed these questions. Absent satisfactory answers to them, no-fault antitrust—or anything close to it—would likely be a recipe for arbitrary and welfare-reducing government regulation.

There is another problem with no-fault antitrust law that suggests that it would have — at best — an uneasy relationship with U.S. antitrust law, although the unease has little to do with the CW standard itself: U.S. antitrust law proscribes certain kinds of conduct and otherwise leaves parties free to compete in the marketplace. In effect, it punishes and seeks to deter what it regards as bad conduct. If one imagines a continuum with proscriptive law enforcement at one end and prescriptive regulation on the other, antitrust law is on the law enforcement side. The law enforcement approach reflects both a normative judgment about the limited role of the State and specific, antitrust judgments: that competition is better than regulation; that markets (policed by rules of fair play) know better than central planners; and that proscriptive rules promote business compliance, legal certainty, and economic activity. If antitrust intervention is based on market conditions rather than specific bad conduct, it becomes a kind of regulation and to that extent departs from a core premise of U.S. antitrust law.

\subsection{Conduct-Based Rules for Platforms}

Other CW critics seems to mean almost the opposite. According to these critics, antitrust law should focus on the conduct, without regard to any market power effects. As Wu (2018) describes it, the point is to make "the antitrust law akin to the "rules of the game," and make enforcers and judges referees, calling out fouls and penalties".

This change does not require jettisoning the $\mathrm{CW}$ paradigm because antitrust law can in principle consist entirely of per se, "quick look", and similar rules that depend on the defendant's conduct and do not require proof of market power effects. ${ }^{59} \mathrm{We}$ doubt, however, that the change would be wise as a policy matter.

The market power element in U.S. antitrust law serves several important purposes: First, it limits antitrust enforcement to those cases that have a material impact on competition and thus serves to weed out cases that do not warrant the often costly and burdensome intrusion of antitrust investigation and litigation. It rests on a reasonable expectation that - absent market power-the market will quickly correct inefficient conduct; and it serves a screening function that reduces the incentive for disgruntled rivals or other third parties to turn every marketplace dispute or alleged

\footnotetext{
59 A narrower version would require pre-existing market power, so that the "fouls and penalties" applied only to dominant firms, and would deem anticompetitive conduct by such firms to be unlawful without proof that the conduct actually did or was likely to cause an increase in market power. That is similar to the approach taken in the quasi per se rule applicable to tying arrangements and in many past cases in the EU, although EU law seems to be moving away from such an approach (Petit 2018). This alternative would avoid some of the problems of a complete abandonment of a market power effects requirement, but it would not have the benefit of avoiding the often difficult task of proving that the defendant had market power.
} 
misdeed into an antitrust case. This function is particularly important in the information economy, where platforms operate as intermediaries between numerous groups of users that are active on multiple sides and may thus - through the exercise of editorial, managerial, or technical discretion—generate negative externalities towards a vast range of private interests.

Second, the market power requirement reduces antitrust compliance costs because it enables firms to act without consulting antitrust lawyers and economic consultants for the vast multitude of matters that plainly do not implicate increased market power. For example, while product integration and pre-installation can raise difficult antitrust issues, the market power screen enables us readily to understand that Facebook Messenger, Apple Pay, and Google Scholar are not unlawful.

Perhaps the weightiest justification for the market power requirement is that it ensures that antitrust law remains focused on the competitive process and is not looked to as a remedy for all sorts of undesirable commercial conduct. Antitrust investigations and litigation are costly. The market power requirement ensures that those costs are incurred only with respect to conduct that is likely to cause an increase market power.

\subsection{False Positives and False Negatives}

The market power requirement reduces the likelihood of false positives in antitrust enforcement because it requires the plaintiff in most cases to establish a second fundamental element. That benefit might be of special importance in platform industries-at least in digital platforms - because those industries have been characterized by short innovation cycles and disruptive innovation. Antitrust enforcement that is based entirely on conduct rules is especially likely to be misguided in such industries: both because the rules will often have to be applied to relatively new forms of conduct or business organization that might be misunderstood; and because the rules - even if sensible when adopted - might no longer make sense when applied in a changed industry. New and unfamiliar business practices that disadvantage competitors or, under some circumstances, one or more groups of trading partners might be erroneously thought to be anticompetitive if the functioning of the market or the business justification is not understood. ${ }^{60}$

But the market power requirement also increases the likelihood of false negatives. It does so both because it requires proof of a second element and thus increases the likelihood of erroneous decisions that are false negatives and because-by

\footnotetext{
${ }^{60}$ Cf., United States v Microsoft, 253 F.3d 34 (D.C. Cir. 2001) (rejecting the "separate demand" test for determining separate products for tying law purposes in software platform markets on the ground that the test is backward-looking and thus not suited for "new and innovative" products). New and unfamiliar business practices might also under some circumstances give rise to false negatives if, for example, they are assessed by application of lenient rules that are designed for different even if somewhat analogous kinds of conduct and the significance of the differences is not appreciated.
} 
broadening antitrust cases - it increases antitrust enforcement costs and might therefore deter antitrust enforcement in the first place. ${ }^{61}$

Whether the current tradeoff between false positives and false negatives is on balance desirable or undesirable is a fair subject for debate. Antitrust courts have tended to show greater concern about false positives than about false negatives: in large part because of a belief that markets can self-correct, while judicial decisions are often permanent (Easterbrook 1984a, b). That view has been criticized for, among other things, painting with far too broad a brush.

Further, the optimal tradeoff might be different in the context of platform industries. On the one hand, false negatives might be especially costly in platform industries if incumbent platforms are less susceptible to market correction because of network effects or other barriers to entry and if anticompetitive conduct by such platforms threatens not just allocative inefficiency but also to retard the innovation process. On the other hand, false positives might be especially costly if they threaten the realization of the benefits of network effects or inhibition of new forms of business conduct or new technologies.

There are many ways that the balance between concerns about Type 1 and Type 2 errors in antitrust law could be recalibrated if relatively more tolerance for false positives and less tolerance for false negatives were thought desirable: The recalibration could take the form of: more per se or quick look rules that do not require proof of market power; increased recourse to presumptions or incipiency tests in merger or unilateral conduct cases (such as the Philadelphia National Bank presumption); new thresholds for specific restraints (e.g., rules of thumb about market shares or duration that is needed to condemn exclusive-dealing arrangements under Section 1); relaxed evidentiary requirements (in, for example, predatory pricing cases); and changed conduct requirements in areas such as refusals to deal and patent manipulation.

The important point for present purposes is that none of these or other changes requires abandoning the $\mathrm{CW}$ framework. To the contrary, by focusing attention on economic welfare, the $\mathrm{CW}$ framework enables a rigorous assessment of the various alternatives.

\section{Conclusion}

The criticisms of the CW standard in platform markets seem to reflect a combination of:

\footnotetext{
61 Critics complain that the focus on existing or ex ante market power, and in particular on the "special responsibility" of dominant firms, has led to increased false positives in EU competition law. See, e.g., Joined cases T-191/98, T-212/98, T-213/98 and T-214/98, Atlantic Container Line v Commission [2003] ECR II-3275 ("Even if the practices on service contracts in question represent the standard practice of maritime carriers, therefore, Article 86 of the Treaty prevented the TACA parties, given their special responsibility as a collective dominant unit on the transatlantic trade, from adopting such practices, notwithstanding the fact that they were adopted by most, if not all, of their competitors").
} 
(1) excessive literalism ("consumer welfare prescription") that has obscured analysis of how antitrust law actually functions; (2) post hoc reasoning that at least partly attributes disappointing economy-wide developments to limitations on antitrust that are caused by the $\mathrm{CW}$ standard; and (3) a presumption that large size, scale or share and increases in industry concentration imply monopoly or oligopoly power in economically meaningful markets.

Unless critics intend to make antitrust law a general tool for attacking all sorts of inequalities in size, power, and wealth that are unrelated to market competition, they will not be able to improve antitrust law by abandoning the $\mathrm{CW}$ standard in platform markets in particular and across industries in general. They should focus their attention, instead, on improving antitrust doctrine within the CW framework.

Acknowledgements The authors thank Al Klevorick, Greg Werden, and roundtable participants at the Competition, Antitrust Law, and Innovation Forum at the University of California, Irvine School of Law for very helpful comments on an earlier draft.

OpenAccess This article is distributed under the terms of the Creative Commons Attribution 4.0 International License (http://creativecommons.org/licenses/by/4.0/), which permits unrestricted use, distribution, and reproduction in any medium, provided you give appropriate credit to the original author(s) and the source, provide a link to the Creative Commons license, and indicate if changes were made.

\section{References}

Alexis, A. (2017). Antitrust Warrior Picks Battle with 'Alt-Left' Activists, Bloomberg Law. https://www. bna.com/antitrust-warrior-picks-n73014464076/. Accessed 22 Jan 2019.

Areeda, P.E. (1972). Antitrust laws and public utility regulation. The Bell Journal of Economics andManagement Science, 3(1), 42-57.

Baker, J., Sallet, J., \& Scott Morton, F. (2018). Unlocking antitrust enforcement. The Yale Law Journal, 127, 1916.

Balto, D. (2008). A progressive vision for antitrust enforcement to protect the opportunities for small businesses and to protect consumers, testimony before the house small business committee hearing on "small business competition policy: Are markets open for entrepreneurs?". http://www.dcantitrus tlaw.com/assets/content/documents/CAP/A\%20Progressive\%20Vision.pdf. Accessed 22 Jan 2019.

Barkai, S. (2016). Declining labor and capital shares. Stigler Center for the Study of the Economy and the State New Working Paper Series 2.

Belleflamme, P., \& Peitz, M. (2018). Inside the engine room of digital platforms: Reviews, ratings, and recommendations. AMSE Working Paper. https://papers.ssrn.com/sol3/papers.cfm?abstract_ id=3128141. Accessed 22 Jan 2019.

Blair, R. D., \& Sokol, D. D. (2013). Welfare standards in US and EU Antitrust Enforcement. Fordham Law Review 81, 2497. http://scholarship.law.ufl.edu/facultypub/360.

Bork, R. (1966). Legislative intent and the policy of the Sherman Act. Journal of Law and Economics, 9, 7.

Bork, R. (1967). The goals of antitrust policy. American Economic Law Review, 57, 242.

Bork, R. (1978). The antitrust paradox: A policy at war with itself. Mumbai: The Free Press.

Bork, R., \& Sidak, J. G. (2012). What does the Chicago school teach about internet search and the antitrust treatment of Google? Journal of Competition Law and Economics, 8(4), 663-700.

Bracha, O., \& Pasquale, F. (2008). Federal Search Commission-Access, fairness, and accountability in the law of search. Cornell Law Review, 93(6), 1149.

Candeub, A. (2014). Behavioral economics, internet search, and antitrust. A Journal of Law and Policy, 9, 407. 
Caves, K., \& Singer, H. (2018). When the econometrician shrugged: Identifying and plugging gaps in the consumer welfare standard. George Mason Law Review. https://ssrn.com/abstract=3205518. Accessed 22 Jan 2019.

Cunningham, C., Ederer, F., \& Ma, S. (2018). Killer acquisitions. https://papers.ssrn.com/sol3/paper s.cfm?abstract_id=3241707.

De Loecker, J., \& Eeckhout, J. (2017). The rise of market power and the macroeconomic implications. NBER Working Paper No 23687.

Díez, F.J., Leigh, D., \& Tambunlertchai, S. (2018). Global market power and its macroeconomic implications. IMF Working Paper, WP/18/137.

Dorsey, E., Rybnicek, J., \& Wright, J. D. (2018). Hipster antitrust meets public choice economics: The consumer welfare standard, rule of law, and rent-seeking. (July 5, 2018). https://papers.ssrn.com/ sol3/papers.cfm?abstract_id=3165192.

Dwoskin, E. (2017). Facebook's willingness to copy rivals' apps seen as hurting innovation, Washington Post, 10 August 2017. https://wapo.st/2HGRuAN.

Easterbrook, F. H. (1982). Response, is there a ratchet in antitrust law? Texas Law Review, 60, 705.

Easterbrook, F. H. (1984a). The limits of antitrust. Texas Law Review, 63, 1-40.

Easterbrook, F. (1984b). Vertical arrangements and the rule of reason. Antitrust Law Journal, 53(1), 135.

Elhauge, E. (2016). Horizontal shareholding. Harvard Law Review, 129, 1267.

Evans, D., \& Schmalensee, R. (2017). Why the claim that markets with two-sided platforms become onesided when they mature is wrong. https://ssrn.com/abstract=3009452. Accessed 22 Jan 2019.

Ezrachi, A., \& Stucke, M. (2017). Looking up in the data-driven economy, University of Tennessee Legal Studies Research Paper No 333. https://ssrn.com/abstract=2975510. Accessed 22 Jan 2019.

Federico, G., Langus, G., \& Valletti, T. (2018). Horizontal mergers and product innovation. International Journal of Industrial Organization, 59, 1-23.

First, H. (2018). Woodstock antitrust, CPI Antitrust Chronicle. https://papers.ssrn.com/sol3/paper s.cfm?abstract_id=3180878. Accessed 22 Jan 2019.

Fox, E. (1986). The politics of law and economics in judicial decision making: Antitrust as a window. New York University Law Review, 61, 554.

Fox, E. (2007). An anti-monopoly law for China-Scaling the walls of protectionist government restraints. Antitrust Law Journal, 74, 173.

Fox, E. (2008a). The efficiency paradox, in how the Chicago School overshoot the mark: The effect of conservative economic analysis on US antitrust. In R. Pitofsky (Ed.), Oxford, p. 77.

Fox, E. (2008b). "The efficiency paradox", how the Chicago School overshot the mark: The effect of conservative economic analysis on US antitrust. In R. Pitofsky (Ed.), Oxford, p. 77, 2008; at p. 79.

Fox, E., \& Sullivan, L. (1987). Antitrust-Retrospective and prospective: Where are we coming from? Where are we going? New York University Law Journal, 62, 579.

Goldberg, J. (2018). Suicide of the west: How the Rebirth of tribalism, populism, nationalism and identity politics is destroying American democracy. Crown Publishing Group.

Guttiérez, G., \& Philippon, T. (2018). How EU markets became more competitive Than US markets: A study of institutional drift. NBER Working Paper No. 24700.

Hart, O., Tirole, J., Carlton, D. W., \& Williamson, O. E. (1990). Vertical integration and market foreclosure. Brookings papers on economic activity. Microeconomics, 1990, 205-286.

Hemphill, S., \& Rose, N. (2018). Mergers that harm sellers. Yale Law Journal, 127, 2078.

Hubbard, S. (2016). As EU continues scrutiny of US tech giants, Amazon is increasingly vulnerable in US to antitrust enforcement for exclusionary conduct in books, Capitol Forum. http://createsend .com/t/j-3B6A398601C6EAE5. Accessed 22 Jan 2019.

Joliet, R. (1970). Monopolization and abuse of dominant position (Martinus Nijhoff).

Kaplow, L. (2016). On the relevance of market power. Harvard Law Review, 130, 1303.

Katz, M., \& Sallet, J. (2018). Multisided platforms and antitrust enforcement. Yale Law Journal, 127, 2142.

Khan, L. (2017). Amazon's antitrust paradox. The Yale Law Journal, 126, 710.

Khan, L. (2018a) The Supreme Court just quietly gutted antitrust law, Vox, 3 July 2018. https://www.vox. com/platform/amp/the-big-idea/2018/7/3/17530320/antitrust-american-express-amazon-uber-techmonopoly-monopsony?_twitter_impression=true.

Khan, L. (2018b). The ideological roots of America's market power problem. The Yale Law Journal Forum, 127, 1962.

Khan, L. (2018c). The new brandeis movement: America's antimonopoly debate. Journal of European Competition Law and Practice, 9, 131. 
Khan, L., \& Vaheesan, S. (2017). Market power and inequality: The antitrust counterrevolution and its discontents. Harvard Law \& Policy Review, 11, 234.

Kovacic, W. (2008). Competition policy in the European Union and the United States: Convergence or divergence? In Bates White Fifth annual antitrust conference, 2 June 2008.

Krämer, J., Schnur, D., \& de Streel, A. (2017). Internet platforms and non-discrimination. CERRE.

Krattenmaker, T., \& Salop, S. (1986). Anticompetitive exclusion: Raising rivals' costs to achieve power over price. The Yale Law Journal, 96(2), 215.

Lande, R. H. (2001). Consumer choice as the ultimate goal of antitrust. University of Pittsburgh Law Review, 62, 503.

Langlois, R. (2018). Hunting the big five: Twenty-first century antitrust in historical perspective, Working Paper 2018-01R, January 2018, Revised April 2018, Department of Economics Working Paper Series, University of Connecticut.

Langlois, G., \& Elmer, G. (2013). The research politics of social media platforms. Culture Machine, 14, 1.

Lerner, A. P. (1934). The concept of monopoly and the measurement of monopoly power. The Review of Economic Studies, 1(3), 157-175.

Leslie, C. (2014). Antitrust made (too) simple. Antitrust Law Journal, 79(3), 917.

Melamed, A. D. (2017). Antitrust law is not that complicated. Harvard Law Review Forum, 130, 163.

Naidu, S., Posner, E., \& Weyl, G. (2018). Antitrust remedies for labor market power. Harvard Law Review Forthcoming. https://ssrn.com/abstract=3129221. Accessed 22 Jan 2019.

Newman, N. (2014). Search, antitrust, and the economics of the control of user data. Yale Journal on Regulation, 31(2), 401.

Newman, J. (2015). Antitrust in zero-price markets: Foundations. University of Pennsylvania Law Review, 164, 149.

Orbach, B. (2011). The antitrust consumer welfare paradox. Journal of Competition Law and Economics 7(1), 133-164. https://academic.oup.com/jcle/article-abstract/7/1/133/750979.

Pasquale, F. (2013). Privacy, antitrust and power. George Mason Law Review, 20(4), 1009.

Patterson, M. (2017). Antitrust, consumer protection, and the new information platforms. Antitrust, 31(3), 97.

Petit, N. (2018). Analysis and reflections intel and the rule of reason in abuse of dominance cases. European Law Review, 43(5), 728-750.

Posner, R. A. (1975). The social costs of monopoly and regulation. Journal of Political Economy, 83(4), $807-827$.

Posner, R. A. (2001). Antitrust law (2nd ed.). Chicago: University of Chicago Press.

Rubinfeld, D., \& Gal, M. (2016a). The hidden costs of free goods: Implications for antitrust enforcement. Antitrust Law Journal, 80, 521.

Rubinfeld, D., \& Gal, M. (2016b). Access barriers to big data. Arizona Law Review, 59, 339.

Salinger, M. (1988). Vertical mergers and market foreclosure. Quarterly Journal of Economics, 103, 345.

Salop, S., \& Scheffman, D. (1983). Raising rivals' costs. American Economic Review, 73, 267-271.

Shapiro, C. (2017). Antitrust in a time of populism, 24 October 2017. https://faculty.haas.berkeley.edu/ shapiro/antitrustpopulism.pdf.

Singer, H. (2018) Ohio V. American Express: Do monopoly platforms deserve special treatment under antitrust? Forbes, 27 February 2018. https://www.forbes.com/sites/washingtonbytes/2018/02/27/ do-monopoly-platforms-deserve-special-treatment-under-antitrust-review-of-ohio-v-american-expre ss/\#53a365f45b1d.

Solow, R. (1957). Technical change and the aggregate production function. Review of Economics and Statistics, 39, 312.

Steinbaum, M., \& Stucke, M. (2018). The effective competition standard-A new standard for antitrust. New York: Roosevelt Institute.

Stucke, M., \& Grunes, A. (2016). big data and competition policy. Oxford: Oxford University Press.

Sunstein, C. (2018). A new view of antitrust law that favors workers. Why the Chicago School (of all places) is looking askance at mergers and monopolies, 14 May 2018. https://www.bloomberg.com/ view/articles/2018-05-14/antitrust-law-gets-a-chicago-school-makeover.

Teachout, Z. (2014), Corporate rules and political rules: Antitrust as campaign finance reform. Fordham Law Legal Studies Research Paper No. 2384182. https://papers.ssrn.com/sol3/papers.cfm?abstr act_id=2384182. Accessed 22 Jan 2019. 
Teachout, Z., \& Khan, L. (2014). Market Structure and political law: A taxonomy of power. Duke Journal of Constitutional Law \& Public Policy 9(1), 37. https://ssrn.com/abstract=2490525 or http://dx.doi. org/10.2139/ssrn.2490525.

The Economist, A lapse in concentration, September 29, 2016. https://www.economist.com/special-repor t/2016/09/29/a-lapse-in-concentration.

The Economist, Nostrums for rostrums, May 26, 2016. https://www.economist.com/leaders/2016/05/26/ nostrums-for-rostrums.

The Economist, The world's most valuable resource is no longer oil, but data, May 6, 2017.https://www. economist.com/leaders/2017/05/06/the-worlds-most-valuable-resource-is-no-longer-oil-but-data.

Tirole, J. (1988). The theory of industrial organization. Massachusetts: The MIT Press.

Turner, D. (1987). The durability, relevance, and future of american antitrust policy. California Law Review, 75(3), 797.

Vaheesan, S. (2017), Accommodating capital and policing labor: Antitrust in the two gilded ages. Maryland Law Review. https://ssrn.com/abstract=3046302. Accessed 22 Jan 2019.

Vaheesan, S. (2018). The twilight of the technocrats' monopoly on antitrust? The Yale Law Journal Forum, 4, 980.

Werden, G. (2014). Antitrust's rule of reason: Only competition matters. Antitrust Law Journal, 79, 713.

Werden, G. J. (2007). Monopsony and the Sherman Act: Consumer welfare in a new light. Antitrust Law Journal, 74, 707.

White, L. J., \& Yang, J. (2017). What has been happening to aggregate concentration in the US economy in the 21st Century? March 30, 2017. https://ssrn.com/abstract=2953984.

Woodcock, R. (2013). Inconsistency in antitrust. University of Miami Law Review, 68, 105.

Woodcock, R. (2017). Antitrust as corporate governance. https://ssrn.com/abstract=3123985. Accessed 22 Jan 2019.

Wu, T. (2018) After consumer welfare, now what? The "protection of competition" in practice. CPI Antitrust Chronicle.

Zingales, L. (2017). Towards a political theory of the firm. The Journal of Economic Perspectives, 31(3), 113.

\section{Case List}

Allen v. Dairy Farmers of America, Inc., 16-1944 (2d Cir. 2017).

Atlantic Container Line v Commission, T-191/98, T-212/98, T-213/98, T-214/98, ECR II-3275 (2003).

Broadcast Music, Inc. v. CBS, Inc., 441 U.S. 1 (1979).

Brooke Grp. Ltd. v. Brown \& Williamson Tobacco Corp., 509 U.S. 209, 220 (1993).

Dentsply International, Inc. v. United States, 399 F.3d 181 (3d Ir. 2005).

Eastman Kodak Co. v. Image Technical Services, Inc. et al., 504 U.S. 451 (1992).

Groupement des cartes bancaires (CB) v European Commission, C 67/13 P, ECLI:EU:C:2014:2204 (CJEU 2014).

Hoffmann-La Roche v Commission, Case 85/76, ECLI:EU:C:1979:36 (CJEU 1979).

Leegin Creative Leather Products, Inc. v. PSKS, Inc., 551 U.S. 877 (2007).

Lindsay Kamakahi v. American Society for Reproductive Medicine, United States District Court, Northern District of Ca., Class Action Complaint, Case No. 3:11-CV-1781 (filed April 12, 2011).

Lorain Journal Co. v. United States, 342 U.S. 143 (1951).

McWane, Inc. v. F.T.C., No. 14- 11363, 2015 WL 1652200, at*19 (11th Cir. Apr. 15, 2015).

National Society of Professional Engineers v. United States, 435 U.S. 679 (1978).

NYNEX Corp. v. Discon, Inc., 525 U.S. 128 (1998).

Ohio v. American Express Co., 585 U.S. (2018).

Rambus Inc. v. FTC, 522 F.3d 456, 466-67 (D.C. Cir. 2008).

Reiter v. Sonotone Corp., 442 U.S. 330 (1979).

State Oil Co. v. Khan, 522 U.S. 3, 20 (1997).

United States v. Aluminum Co. of America, 148 F.2d 416 (2d Cir. 1945).

United States v. Anthem, No. 17-5024 (DC Cir. 2017)S Seaman v. Duke University, No. 1:2015cv00462 Document 189 (M.D.N.C. 2018).

United States v. Cargill, Inc. and Continental Grain Co. Civil No. 99-1875 (GK) (filed July 8, 1999).

United States v. Microsoft Corp., 253 F.3d 34 (D.C. Cir. 2001). 
Verizon Communications Inc. v. Law Offices of Curtis V. Trinko, LLP, 540 U.S. (2003).

Weyerhaeuser Co. v. Ross-Simmons Hardwood Lumber Co., 549 U.S. 312 (2007).

\section{Other}

Guidance Communication on the Commission's enforcement Priorities in Applying Article 82 of the EC Treaty to Abusive Exclusionary Conduct by Dominant Undertakings, OJ C 45 2009, 7-20.

International Competition Network, Competition Enforcement and Consumer Welfare - Setting the Agenda, 2011.

OECD hearing on Across Platform Parity Agreements, Note by the US, DAF/COMP/WD(2015)72.

OECD, Roundtable on Monopsony and Buyer Power, 2008, Note by the US, DAF/COMP/WD(2008)79.

U.S. Department of Justice and Federal Trade Commission, Horizontal Merger Guidelines $§ 4$ (2010).

Publisher's Note Springer Nature remains neutral with regard to jurisdictional claims in published maps and institutional affiliations. 